\title{
Global Financial Governance: a Perspective from the International Monetary Fund
}

\author{
Ryszard Wilczyński
}

\begin{abstract}
An environment for the activities of the International Monetary Fund (the IMF) has fundamentally changed over the two recent decades. The strong development of financial innovations as well as of financial globalisation was among major forces driving the change and shaping the economic growth worldwide. As some economies were able - with the support from financial markets - to accelerate their growth, other countries suffered from turbulences, which were reinforced and transferred internationally through the volatile financial markets. The process of international financial contagion makes the case for global financial governance, which so far has been left behind the development of markets. The IMF is mandated to play a central role in the global governance designed to ensure financial stability. The article reconsiders the Fund's role and includes an overview and assessment of its activities, particularly in the context of the global financial crisis in 2007-2010. In the aftermath of this crisis, the international financial stability may, however, again be at risk as several external imbalances in the global economy may be hardly sustainable. It is argued in the paper that, in addition to a gradually improving surveillance and lending as well as to adjusting resources by the Fund, an enhanced credibility of the institution is needed so that its role in the process of the stabilising global financial system is strong and effective.
\end{abstract}

Key words: international financial contagion; global financial governance; financial crisis; global imbalances; IMF.

\section{JEL Classification: F33, F53.}

${ }^{1}$ Faculty of Management and Finance, University of Finance and Management in Warsaw, Poland

\section{Introduction and Overview}

Several recent decades have been witnessing an increasing deepening of financial systems as well as their international broadening. The development of financial systems - in terms of the quantity, quality and diversity of market participants, procedures, instruments as well as resources - has been impressive. Simultaneously, the pace of integrating domestic financial systems into an international network has accelerated and fuelled the process of financial globalisation, bringing it ahead of the globalisation of other sectors of the economy.

The links of finance to growth have been extensively examined in the economic literature. These linkages

Corespondence concerning to this article should be addressed to: Ryszard.Wilczynski@mofnet.gov.pl rank among the fundamental topics in the analysis of growth. The interest of economists and policy makers in the link between finance and growth has been motivated - to a large degree - by the performance of the US economy, which is most advanced in both economic and financial terms. For many years, the US has been achieving relatively high GDP growth rates while, simultaneously, enjoying rapid development of the financial sector and providing a benchmark for other countries.

There is a strong view advocating that, domestically, financial development positively affects growth. This view rests heavily on the assumption of perfect financial markets, which are also efficient. Improved financial markets, institutions and products can affect growth by raising the fraction of savings available for 

cial crisis to a world recovery coincides with the 65th anniversary of the Fund. In the economic literature, positive assessments of the IMF role in stabilising the international financial system and enhancing growth, particularly of economies under transition, have been - over time - increasingly joined by the criticism of the institution (e.g. Feldstein, 1998; Radelet \& Sachs, 1998; Stiglitz, 2002).

The article reconsiders the IMF role and identifies avenues for its strengthening. It is organised as follows. Section 1 discusses an increasing international financial contagion which makes the case for the global financial governance. In subsequent sections, several areas of IMF policies, which are relevant for financial contagion, are examined: those regarding international capital flows (section 2); surveillance, exchange rates and global imbalances (section 3) and lending policies (section 4). Some issues of the Fund's internal governance, which affect the credibility of the institution, are discussed in section 5 . The final section briefly concludes.

\section{Financial Contagion and the Case for Global Governance}

The 1990s and 2000s brought a tremendous increase in the magnitude of the international financial flows, together with the surge in their volatility. Several big crisis episodes affected some economies and spread to others. Apart from the 2007-2010 US-rooted global crisis, there were two major waves of turbulence on financial markets affecting a remarkable number of both emerging and advanced economies. In the mid-1990s, turbulences started as currency crises and spread to other financial segments and to real sectors of emerging economies, ranging from Mexico to East Asia, with Russia and Brazil as major cases. In the early 2000s, an excessive boom in high-tech assets valuations in the US, together with the WorldCom, Enron and Arthur Andersen defaults, has ignited a recession in the US, which has spread to other advanced economies in Europe and has also coincided with financial disruptions in emerging economies like Argentina, Turkey and Ecuador. In 2007, the collapse of the world's largest US financial sector took the real economy down to a deep recession and the US financial and economic turmoil has developed into a global crisis.
The global financial governance becomes an issue when the process of spreading financial turbulence across countries - referred to as financial contagion is gaining momentum.

Two factors are relevant for contagion. First, it is an involvement of the systemically important economy or of the financial centre (they are usually the same area), which may be the source of strong regional, or even world-wide, spillovers. The common shocks, such as a steep rise in world interest rates, strong deterioration of global output or sharp shifts in investors' sentiment, are usually rooted in developments in large and significant economies. The Latin American debt crisis of the 1980s as well as the Mexican crisis in 1994/95 was triggered by a considerable increase in US interest rates. In 2007, the turmoil of the US financial sector and the collapse of demand in the US has ignited a credit crunch and a deterioration of economic activity in many countries as well as the flight of investors to a safe haven from economies perceived as vulnerable to the crisis, sometimes regardless of their fundamentals.

Secondly, financial (and other) linkages serve as channels for contagion and affect its magnitude. These linkages are likely to be considerable among neighbouring economies and manifest themselves in the form of large, cross-border financial exposures.

The large presence of Western European banks in Eastern Europe during the 2007-2010 financial crisis is a relevant case. Prior to the crisis, Western European parent banks have been increasingly funding their subsidiaries in Eastern Europe in order to allow them to meet the rapidly growing demand for loans. However, in case of problems on any side and regardless of their reputational considerations, parent banks might be unwilling or unable to continue lending to their subsidiaries. In Europe, an increasing size of parent subsidiaries, or more broadly, home-host exposures, have been enhanced by their growing concentration as well as by "the common lender" cases, and resulted in the magnified regional financial contagion.

The case for the mutual non-negligible exposures, heavy concentration and, therefore, serious but confined contagion risks, refers to Swedish bank ownership in the Baltic states. The region-wide contagion was - in the early 2009 - more likely in the case of Austrian banks, which are visibly exposed and more diversified across emerging Europe and could be the 

financial resources across countries more efficiently. This common goal, or a public good, implies an effort undertaken by a number of countries together; since then, it is more effective. In the past, international governance actions have been heavily influenced by national and regional considerations. Global financial governance seems to have been "left behind the curve". Over time, a coordinating approach has been increasingly declared, although less often implemented. Governance actions should be designed to better identify financial interconnectedness and locate, assess and eliminate the weak spots in the financial network, which are relevant for building up systemic risk. The IMF is the natural platform to play the central role in these actions.

\section{IMF and International Capital Flows}

The stability of the international financial system depends, to a considerable degree, on international capital flows. These flows have surged during the last two decades. An accelerated growth of capital flows reflects - in broad terms - the progress in financial globalisation, with the IT revolution and the explosion of financial innovations as strong contributing factors. Private capital flows from industrial to developing economies have increased from 174 billion dollars during the 1980 s to 1.3 trillion dollars during the 1990s (Summers, 2000). During the 2000s, these flows have increased further; they peaked around 2007 and, after a deterioration during the global financial crisis, they continue increasing during and after 2010. International capital flows have dwarfed trade flows and replaced them as the determinant component of the payments balances .

Together with the growth in magnitude, an increased volatility of capital flows has been one of the profound developments in international finance over recent decades. The waves of surges and drops in capital flows can be identified. The excessive surges in inflows were among factors leading to the currency and financial turmoil in several countries. The Latin American debt crisis in the 1980s, the Asian currency crisis in 1997 or the global financial crisis in 2007-2010 were preceded by considerable surges in capital inflows to emerging economies. Those inflows, however, suddenly and abruptly reversed, directly contributing to the eruption of the crisis and catalysing financial contagion. In each case, the confidence of investors to the whole class of emerging economies has dropped visibly.

Historic examples of the nexus between the capital flows and the rate of economic growth as well as its volatility are considerably mixed. During the 2000s, several economies of emerging Europe were able to converge with Western Europe largely due to an increased inflow of external private capital, even allowing for the positive impact of their EU membership (Cihak \& Mitra, 2009). However, an extremely rapid growth is also possible with capital flows that are not liberalised as can be demonstrated by the experience of Japan in the 1950s and the 1960s and of China in the 1990s.

Regarding growth volatility, examples of capital flows which help stabilise growth refer mainly to FDI, while in the case of non-FDI flows, the opposite impact dominates the picture. In particular, Williamson concludes that in the late 1990s, the most affected by the crisis was economies with liberalised capital flows, such as Thailand, Indonesia, Malaysia, Korea, whereas other countries, such as China or India, with similar macroeconomic characteristics but less liberal on capital flows turned out to be relatively resilient (Williamson et al., 2003). Against this diversity of individual examples, it is not surprising that the evidence from cross-country studies, with differences in methodology, is also not clear-cut.

The issue of international capital flows is linked to IMF responsibilities, namely those for the stability of the international monetary system as well as for exchange rates and payment balances of Fund members. In 1944, under Article VI of the Articles of Agreement countries, they were permitted, when they considered as necessary, to exercise control over overall capital flows, whereas the role of the IMF was limited and somewhat ambiguous. The decision undertaken in Bretton Woods reflected concerns over volatile international capital movements and their effects undermining the independence of national policies in the interwar period. The new, post-war monetary system was supposed to be stable and to encourage trade and growth.

Many perceive the IMF as an institution, which has permanently, strongly and indiscriminately been advocating capital account liberalisation. This is not accurately so; at both conceptual and operational levels, the 

them, as non-binding recommendations, in bilateral and multilateral surveillance. The issue is pressing as the IMF is given the responsibility to ensure the stability of the international financial system, for which the stability of capital flows is highly relevant.

\section{IMF Surveillance, Exchange Rates and Global Imbalances}

Promoting exchange rate stability is among the purposes of the IMF. This objective is clearly related to other key purposes of the institution, such as facilitating the growth of international trade, preventing disequilibrium in the external balances of members as well as cooperation on international monetary problems (Article 1 of the Articles of Agreement). In order to achieve these purposes, the Fund is entitled to exercise firm surveillance over the exchange rate policies of members. The surveillance process should address monetary stability not only of individual countries, but also of the whole international system to ensure its effective operation (Article IV, Section 3).

Exchange rate policies include several issues like the exchange rate regime and level and its misalignment as well as other problems, such as international competitiveness and external imbalances, which are directly affected by the exchange rates.

The issue of the optimal exchange rate regime has been debated among economists for a long time. The debate gained particular momentum in the 1970's, after the Bretton Woods system was replaced with the system of floating exchange rates among major currencies. In the increasingly open economies, the choice of the exchange rate regime significantly affects macroeconomic policies.

Different regimes, in particular for emerging market economies, have been advocated over time. The overall advocacy moved from fixed - in the early 1990s - to floating regimes around the end of the decade; then the support turned to a bipolar view, to corner solutions at the detriment of intermediate regimes, and again towards flexible systems, to ultimately lead to the conclusion that there is no unique, best regime. Each regime has its strengths and weaknesses. What matters is rather an individual macroeconomic environment. A currency board worked well in Hong Kong in 19971998 during the time of the Asian crisis, but collapsed in Argentina in 2001. In 2008-2009, a floating regime helped Poland weather the crisis well and did not help Hungary. Similarly, under the managed floating regime in 2009, Indonesia was able to maintain high growth rate, while Thailand and Malaysia fell into recession. It has to be emphasised that the IMF members have the right to determine their own exchange rate regime.

The Fund should not be in a position to directly determine the optimal level of the exchange rate. Identifying misalignments with the equilibrium level, that is based on fundamentals, should not be equivalent to fine-tuning the exchange rate configuration. However, the institution needs quantitative assessments in order to be able to provide advice on exchange rate policies of its members. These assessments carried out under bilateral surveillance should be consistent with the circumstances in the global monetary setting examined by multilateral surveillance. The Fund's role on exchange rates is extremely complex and politically difficult.

In an uncertain environment of the aftermath of the Bretton Woods system in 1977, the IMF has approved the Decision on surveillance. The Decision narrowed the scope of the Fund's responsibility as it focused exclusively on the bilateral exchange rate surveillance. In particular, the Decision addressed the problem of devaluations designed to gain an unfair competitive advantage. The Fund's Decision, however, failed to fully address issues arising from financial globalisation, which are also relevant to the exchange rates.

Two recent decades saw the process of building up global imbalances, i.e. of a pattern of large current account surpluses in some economies and deficits in others. On the surplus side, the leading economies of China and Japan were joined by other East Asian countries, Middle East and other major oil exporters, and Germany. The deficit side is dominated by the US and includes also the UK as well as countries of Southern and Eastern Europe. In the peak 2006 year, the US deficit was around $6 \%$ of GDP, while the Chinese surplus climbed to almost $10 \%$ of the GDP.

The concerns over such a pattern have been increasing over time. It was argued that imbalances originate from distortions, such as a bubble-driven asset inflation and excessive public borrowing in deficit countries (e.g. Cline, 2005). Other causes of imbalances were identified: the underdevelopment of financial systems, lack of social insurance, export-led growth with undervalued currencies and excessive accumulation of reserves 

depends upon the credibility of the institution. The Fund's credibility has been, and still is, challenged; the process of necessary governance reforms is on track, but not yet completed.

In order to improve surveillance over exchange rate policies and to reinforce its implementation, in 2007, the IMF has amended the 1977 Surveillance Decision. The main objective was to extend the Fund's surveillance on all major causes of external instability related to the exchange rate policies, in particular, to equip the IMF with the power to deal, in addition to competitive devaluations, with restraining by members' appreciation, that would be consistent with fundamentals. The new concept of "external stability", i.e. the balance of payment position, that is not generating - and not likely - to generate disruptive exchange rate movements, was expected to be useful in extending the scope of surveillance. However, major players remain immune to the IMF recommendations regarding external stability; if these recommendations are not implemented, Article IV remains formally unbroken. What may be harmed here is rather (only) the reputation of the country.

During the global crisis, the Fund has shown pragmatism, tailoring its recommendations on exchange rates to individual circumstances. In the case of Latvia, the IMF ultimately decided on maintaining the peg and did not insist on devaluation, which would entail negative spillover effects for the credibility of fixed regimes in neighbouring countries aiming, as Latvia is, to implement the euro. In the case of Iceland, the Fund has taken into consideration the need for financial flexibility and was in favour of a float.

Recent research on exchange rate regimes, including work done within the IMF, explores particular strengths and weaknesses of pegged, intermediate and floating regimes, with the crisis risk to a country and to the speed of adjustment as well as risks to the whole international monetary system as key factors in trade-offs around the regimes (Ghosh et al., 2010). One of the challenging options for future research on exchange rate policies could be the monetary union and paths of the euro adoption since current policies of candidate countries vary broadly.

\section{IMF Lending}

Like surveillance, IMF lending also serves multiple purposes for the Fund. In particular, IMF lending pro- grammes are instrumental not only in the resolution of the crisis in a member country's economy, but also - through improving market confidence in a member - in the crisis prevention. They also help attract financing from sources other than the IMF (i.e. they catalyse financing) and help restrict the financial contagion. In order to fulfil these roles, the Fund needs adequate financial resources as well as efficient vehicles necessary to channel funds when and to where they are needed.

Restricting contagion is particularly important in the global context. In theory, by providing liquidity when private providers are reluctant to provide, the Fund helps prevent or reduce default of a debtor country and that outcome benefits also other countries. Otherwise, the equilibrium world interest rates would go up and borrowing costs would increase, which is a negative externality; such an effect is also generated by the deterioration of the macroeconomic situation by a systemically important economy (Clark \& Huang, 2001).

The demand for IMF resources has significantly fluctuated over the past two decades. The 1990s and the early 2000s saw surges in demand due to lending programmes, which supported transformations in an emerging Europe as well as due to the wave of financial crises in emerging economies, from Mexico in 19941995 to Argentina in 2001. Thereafter, until 2007, the trend has reversed for several reasons, including ample global liquidity; reduced vulnerabilities and, therefore, also needs for the balance of payment financing, an improved access for many developing economies to private financing as well as considerable growth of foreign reserves in these economies.

The global crisis of 2007-2010 has strongly tested the Fund's financing role. In 2008 and 2009, many emerging and developing economies experienced dramatic declines in capital inflows and in trade. The demand for IMF financing has sharply increased. From September 2008 until March 2010, 21 countries applied for the IMF loans under stand-by arrangements totalling up to 57 billion dollars, whereas three countries applied for the flexible credit lines, which almost doubled stand-by lending and brought the total lending commitments of the Fund to approximately 160 billion dollars.

Responding to the severe crisis, the IMF has taken extraordinary decisions on its resources. An additional allocation of SDR equivalent to 250 billion dollars and 

in the internal governance of the institution as well as in the quality of surveillance and lending as perceived by some members.

An internal governance has several components, which affect, directly or indirectly, the process of decision making. In the case of the international cooperative institution, the appropriate voting structure is of prime significance. The voting structure in the IMF is largely determined by the structure of members' quotas, which are slightly corrected with the system of basic votes.

The objective of the IMF quota is to reflect a country's weight in the global economy and in the international financial system. The widespread recognition remains that the current quota structure still fails to meet its main objectives. The quota reforms agreed in 2008 and 2010 will improve the alignment of the quota structure with the structure of the global economy and finance, but these reforms are not yet effective. Under the current quota structure, emerging economies are, in broad terms, under-represented while advanced countries are over-represented. What matters here is the benchmark for the representation. Under the most usual and standard measurements, i.e. the country's GDP-PPP share in the world GDP, the combined quota share in 2009 of four BRIC's - Brazil, China, India and Russia - plus Mexico, was approximately 100\% lower than what it should have been. In the case of the Eurozone economies combined, the misalignment was at approximately $50 \%$ to the opposite (see Table 1).

In addition to the GDP, IMF quotas include three other components: trade openness, international reserves and variability of flows. BRIC's plus Mexico are modestly under-represented in terms of trade openness (measured with exports) and strongly underrepresented in terms of reserves, whereas the US and the Eurozone countries remain, although to a different degree, over-represented (except trade openness in the case of the Eurozone). These misalignments are illustrated below.

Table 1. Macroeconomic measurements and IMF quotas of different economies in 2009 (\% shares of totals)

\begin{tabular}{|c|c|c|c|c|}
\hline & GDP-PPP & Exports & $\begin{array}{l}\text { International } \\
\text { reserves }\end{array}$ & IMF quotas \\
\hline US & 20.5 & 9.9 & 1.7 & 17.7 \\
\hline Eurozone & 15.2 & 28.8 & 9.1 & 23.1 \\
\hline BRICs + Mexico & 25.7 & 15.1 & 44.5 & 12.2 \\
\hline
\end{tabular}

The pattern of the relative over- and under-representation in the Fund is more complex. Among emerging economies are also over-represented countries, such as Saudi Arabia, South Africa, Argentina, Pakistan or Nigeria, whereas some of the advanced countries, such as Spain, Ireland or Luxembourg, are underrepresented. However, many sizeable Asian emerging economies, including China, Turkey, South Korea, Thailand or Vietnam, remain clearly under-represented. Under the 2010 quota reform, there is a consensus on an ad hoc $6 \%$ shift of quota shares to dynamic emerging and developing countries, but it remains to be seen whether it is satisfactory across the membership or further quota adjustments and realignments will be demanded.
Everything above the quotas assumes that the current quota formula is adequate. However, the formula is being contested on several fronts. One of the proposals assumes incorporating the population variable into the formula, which would be much in favour of large emerging economies (population of BRICs plus Mexico is approximately 10 times higher than that of the US or the Eurozone). Another possible avenue is to include some measurements of the financial openness of the economy. A discussion on the quota formula is to be reopened soon and to be completed until 2013. 


\section{Conclusions}

Over time, the IMF has been making strong efforts designed to improve its policies in order to efficiently cope with the challenges originating from the continuously and increasingly changing financial environment. These challenges can be attributed to an increased volatility in international financial markets, which resulted in more frequent and deeper financial crises over the two recent decades. Financial crises were spread internationally with the process of the financial contagion. Those developments call for enhancing the global financial governance and the Fund is designed and equipped to play the central role in this process.

In response to the challenges, the IMF has been improving its surveillance and lending policies as well as adjusting its resources, but the institution did not avoid mistakes and criticism. In the aftermath of the 20072010 global financial crisis, several risks to the stability of the international financial system still remain and they represent remarkable problems for the Fund.

It is reasonable that the IMF policies continue shifting the major emphasis from the crisis resolution to the crisis anticipation and prevention areas. The Fund should also remain sensitive to an increasing role of those policies and instruments, which go beyond the national scope. It is also desirable that the IMF improves its credibility through a more adequate distribution of the quota shares and of the voting power. The distribution of quotas needs further realignments of quota shares to real weights of Fund members in the global economy and finance. Finally and beyond the scope of this paper, an enhancing of the Fund's role in the global financial governance depends also on the proper delineation of competencies between the IMF and other international financial institutions in order to avoid overlaps as well as loopholes in the process.

\section{References}

1. Abiad, A., Leigh, D., \& Mody, A. (2007). International finance and income convergence: Europe is different, IMF Working Paper, No. 64.

2. Arvai, Z., Driessen, K., \& Otker-Robe, I. (2009). Regional financial interlinkages and financial contagion Within Europe, IMF Working Paper, No. 6.

3. Blanchard, O. \& Milesi-Ferretti, G-M. (2009). Global imbalances: In midstream?, IMF Staff Position Note, No. 29.
4. Cihak, M. \& Mitra, S. (2009). Losing their halo, Finance and Development, No. 2.

5. Clark, P. \& Huang, H. (2001). International financial contagion and the IMF: a theoretical framework, IMF Working Paper, No. 137;

6. Cline, W. (2005). The United States as a debtor nation, Institute of International Economics, Washington D.C.

7. Corsetti, G., Pesenti, P., \& Roubini, N. (1998). Paper tigers? A model of Asian crisis, NBER Working Paper, No. 6783.

8. Eichengreen, B. (2008). Should there be a coordinated response to the problem of global imbalances? Can there be one?" DESA Working Paper, No. 69.

9. Eichengreen, B. \& Mussa, M. (1998). Capital account liberalisation and the IMF, Finance and Development, No. 4.

10. Feldstein, M. (1998). Refocusing the IMF, Foreign Affairs, 77(2).

11. Fischer, S. (1998). Capital account Liberalisation and the role of the IMF in: Should the IMF pursue capital account convertibility?, Essays in International Finance, No. 207, Princeton University.

12. Flood, R. P. \& Garber, P. M. (1984). Collapsing exchange rate regimes: Some linear examples, Journal of International Economics, Vol. 17.

13. Frankel, J. A. (2010). Monetary policy in emerging markets: A survey, NBER Working Paper, No. 16125.

14. Ghosh, A.R., Ostry, J.D., \& Tsangarides, C. (2010). Exchange rate regimes and the stability of the international monetary system, IMF Occasional Paper, No. 270.

15. Goldstein, I. (2005). Strategic complementarities and the twin crises, Economic Journal, Vol. 115, April

16. Greenwald, B. C. \& Stiglitz, J. E. (1986). Externalities in economies with imperfect information and incomplete markets, Quarterly Journal of Economics, Vol. 101.

17. Helleiner, E. (2009). The contemporary reform of global financial governance: Implications and lessons from the past, UNCTAD G-24 Discussion Paper Series No. 55, New York.

18. Henry, P. B. (2007). Capital account liberalisation: Theory, evidence and speculation, Journal of Economic Literature, Vol. 45, No. 4. 
19. IMF (2010). Global financial stability report, April. 2010

20. Kengyel, A. (2009). The importance of EU-level regional development policy and the effects of transfers, Euro-Mediterranean Economics and Finance Review, Vol. 4, No. 1.

21. Khan, M.S. \& Senhadji, S.A. (2000). Financial development and economic growth: An overview, IMF Working Paper, No. 209.

22. King, R. \& Levine, R. (1993). Finance and growth: Schumpeter might be right, Quarterly Journal of Economics, Vol. 108, No. 3.

23. Kose, M.A., Prasad, E., Rogoff, K., \& Wei, S.-J. (2006). Financial globalisation: A reappraisal, IMF Working Paper, No. 189.

24. Krugman, P. (1979). A model of balance of payments crises, Journal of Money, Credit and Banking, Vol. 11.

25. Levine, R. (1997). Financial development and economic growth: Views and agenda, Journal of Economic Literature, Vol. 35, No. 2.

26. MacFarquhar, R. \& Pinder, J. (2004). Who would bear the cost of a CEE bailout?, Goldman Sachs Global Economic Research, January 29.

27. Mateos y Lago, I., Duttagupta, R., \& Goyal, R. (2009). The debate on the international monetary system, IMF Staff Position Note, No. 26.

28. McKinnon, R. I. (1973). Money and capital in economic development, Brookings Institution, Washington, D.C.

29. McKinnon, R. I. \& Phil, H. (1996). Credible liberalisation and international capital flows: the overborrowing syndrome, Financial Deregulation and Integration in East Asia (T. Ito, A. Kruger (Eds.)), The University of Chicago Press, Chicago.

30. Obstfeld, M. (1994). The logic of currency crises, NBER Working Paper, No. 4640.

31. Obstfeld, M. (1996). Models of currency crises with self-fulfilling features, European Economic Review, Vol. 40, No. 3-5.

32. Ostry, J. D., Ghosh, A. R., Habermeier, K., Chamon, M., Qureshi, M. S., \& Reinhardt D. (2010). Capital inflows: The role of controls, IMF Staff Position Note No. 4

33. Radelet, S. \& Sachs, J. (1998). The onset of the East Asian financial crisis, NBER Working Paper, No. 6680
34. Stiglitz, J. E. (2002). Globalisation and its discontents, W. W. Norton \& Co.

35. Summers, L.H. (2000). International financial crises: Causes, prevention, and cures, The American Economic Review, Vol. 90, No. 2.

36. Williamson, J., Griffith-Jones S. \& Gottschalk R. (2003). Should capital controls have a place in the future international monetary system. Paper presented at the Conference on the Future of the International Monetary System held by Reinventing Bretton Woods Committee, Madrid.

37. Xafa, M. (2007). Global imbalances and financial stability, IMF Working Paper, No. 111. 